\title{
RECONSTRUCTION \\ NATIONAL SOCIAL SATISFACTION SYSTEM FOR HEALTH FIELD IN THE AUTONOMY REGION WITH VALUE OF WELFARE
}

(deleted or review purposes)

\author{
Gunarto, Urip Santoso \\ Faculty of Law, Sultan Agung Islamic University, Semarang \\ Email : gunartowr2@yahoo.com
}

\begin{abstract}
The objective of this research is to understand and analyze the National Social Security System Construction of Health Sector in the current positive law, to understand and to analyze the weaknesses of the National Social Security System in the Field of Health today and to analyze and reconstruct the National Social Security System for Health Based on the value of welfare Research is expected to have both theoretical and practical uses that researchers use is socio legal research, this research approach is chosen to see how far the effectiveness of law in the prosperity of the community especially in health insurance coverage, here the law is not only seen in terms of its effectiveness but Also related to non-legal factors such as institutions related to the welfare of the community. The Legal System of the Health Insurance Program with the participation of BPJS is still very weak both in terms of the legal substance component, in providing equitable welfare in obtaining health services through the Health Insurance Program with. Strengthening Components of Legal Substances by changing Article 39 Paragraphs (1), (3) and (4) of Presidential Regulation No. 12 of 2013, Strengthening Legal Structure Components by Strengthening FKTP I on the regulation of Government Regulation, Strengthening Legal Culture Component by developing Culture of community law through continuous education to the community so that the community, the Government is not responsible for providing funds for Beneficiaries of Contribution (PBI).
\end{abstract}

\section{Keywords : Social, Security, Health}

\section{A. Introduction}

Health is one of human rights in addition to the right to obtain a livelihood such as clothing, food and boards that are suitable for humans. Health is one of the basic human rights that everyone has the right to get 
it, health is also one of the elements of welfare that must be realized in accordance with the ideals of the Indonesian nation as referred to in Pancasila and the 1945 Constitution of the State of the Republic of Indonesia. ${ }^{1}$

One of the national goals of the Indonesian nation as embodied in the Preamble of the 1945 Constitution, namely the promotion of public welfare. This shows that since the independence of the Unitary State of the Republic of Indonesia has firmly established the concept of the Welfare State (welfare state). ${ }^{2}$ Citizens (basic needs), social servants and market economic interventions. Welfare state is the responsibility of the state in the fulfillment of basic needs which is the right of the citizens and if the government can not perform it then citizens can demand according to the rule of law. ${ }^{3}$

The main obstacles to poor public health services are health financing and transportation, facilities. Social health protection schemes for the poor have been able to improve access to health care, but have not fully improved the health status of the poor due to inadequate basic health facilities, especially for backward, remote, border and island areas. Many factors are causing inequality of services that lead to increased health costs, including changes in disease patterns, health technology developments, outsource-based health financing schemes, and government subsidies for all lines of service, as well as healthcare inflation over other sectors. ${ }^{4}$

Article $28 \mathrm{H}$ paragraph (1) of the 1945 Constitution of the Republic of Indonesia affirms that every person is entitled to health services. Then in Chapter XIV Article 33 paragraph (1) affirms the Economy is prepared as a joint effort. Based on the principle of kinship. Paragraph (2) affirms that the earth, water, and natural resources contained therein are controlled by the State and used for the greatest prosperity of the people. Furthermore Article 34 Paragraph (1) affirms that the poor and neglected children are kept by the State, paragraph (2) affirms the State develops

${ }^{1}$ Ali Taher Parasong, Mencegah Runtuhnya Hukum, Grafindo, Jakarta, 2014

${ }^{2}$ Ramesh Mishra, Welfare State in Crisis, Social Thought and social Change, Wheatsheaf Books Ltd,Harverster Press,London,1984, xi, Dalam Djauhari, , Politik Hukum Negara Kesejahteraan Indonesia, Semarang, Indonesia. 2008

\footnotetext{
${ }^{3}$ Agung Kurniawan, Trasnformasi Pelayanan Publik, Pembaharuan, Yogyakarta, , 2003 ${ }^{4}$ Depkes RI, Pedoman Pelaksanaan Jaminan Pemeliharaan Kesehatan Masyarakat Miskin, Jakarta ,2006
} 
social security system for all people and empowers the weak and incapable of human dignity, paragraph (3) Responsible for the provision of appropriate health services and public facilities.

The relationship between Article $28 \mathrm{H}$, Article 33 and Article 34 of the 1945 Constitution of the Republic of Indonesia indicates that the development of general welfare, especially in providing services and social security, is the right of every citizen and the obligation of the Government of the Unitary State of the Republic of Indonesia to fulfill it ${ }^{5}$. Law Number 40 Year 2004 regarding National Social Security System and Law Number 24 Year 2011 regarding the Establishment of Social Security Administering Body (BPJS) and Presidential Regulation Number 12 of 2013 on National Health Insurance stipulated since January 1, 2014 is a form of commitment Government in providing welfare (state welfare) in the form of health protection for all Indonesian people. The establishment of the Social Security Administering Body (BPJS) of health as the provider of Health Insurance is expected to answer and respond to various challenges of health development in the present and in the future. ${ }^{6}$

The existence of an enhanced National Health Insurance System is of paramount importance given that the current development of health care is increasingly complex in line with the complexities of democratic development, decentralization and globalization and other challenges that are also heavier, rapidly changing and, often uncertain. In the era of regional autonomy under Law No. 23 of 2014, the health sector is one of the affairs that become regional affairs. This makes the local government should prepare and improve services in the field of health as a whole. The policy of regency/ municipality government in the field of health should support national policy in the National Social Security System as stipulated by Law No. 40 of 2004 on National Social Security System, whose implementation is stipulated by Law Number 24 Year 2011 on Social Security Administering Body (BPJS). ${ }^{7}$

In carrying out the mandate of the Constitution the Government has endeavored to provide Social Security Health Protection for its people. In practice there are problems, among others, there is a tendency for the

\footnotetext{
5Undang-undang Nomor 36 Tahun 2009 tentang Kesehatan

${ }^{6}$ Deprtemen Kesehatan, diunduh pada tanggal 12 maret 2014 pada situs yang beralamat, http://www.depkes.go.id/downloads/SKN\%20final.pdf
}

${ }^{7}$ Margaretha Yuliani, Menyongsong BPJS Kesehatan 2014 ,Jaminan Kesehatan :Hak Rakyat-Kewajiban Negara, Depkes RI,Jakarta, 2013 
public to assume that the Social Security Administering Body (BPJS) in the Health field bears all the financing of health services according to the wishes or real needs. While the Health Insurance program with the participation of BPJS this type of service provided has been packaged as efficiently as possible by using generic drugs and limited both in terms of types and amounts in get BPJS participants as the sound of the Decree of the Minister of Health No. 328/Menkes/IX/2013 on the National Formulary. This is far different from the types of services provided in previous health insurance programs such as Public Health Insurance (Jamkesmas) or Askes Participation in which providers can prescribe patent medicines to patients who have been resistant to certain types of drugs.

Another problem is the culture of society that is still low on the maintenance of health and culture Clean and Healthy Life (PHBS) as a promotive effort (improvement) and preventive (prevention). Some people have not made health as a requirement so that people only come to health facilities when they have fallen ill to get services that are curative (treatment) and rehabilitative (recovery). Problems also arise related to BPJS Health payment system to provider. As stated in Article 39 paragraph (1) of Presidential Regulation No. 12 of 2013 on National Health Insurance (JKN), the payment of BPJS Health to FKTP I with Kapitation system is the payment made pre-effort based on the participants registered in FKTP I. The use of the capitation fund Is to pay for medical services/ services $(60 \%)$ calculated on different points for each health professional profession. Differences in the calculation of points in each health profession cause a sense of injustice for the officer. This is because in providing services to patients can not be done by one profession only but required good cooperation between relevant officers according to the flow of service.

The above phenomenon affects the function of the Social Security Administering Body (BPJS) of health which originally aims to provide guarantees to all civil society, military/ police, the poor, self-sufficient communities both in urban and rural areas are still experiencing many obstacles both in terms of administration and technical. Based on the above description it is necessary to conduct research on the Reconstruction of the National Social Security System for Health Sector in the Era of Regional Autonomy Based on Welfare Value. ${ }^{8}$

${ }^{8}$ Undang-Undang Nomor 24 Tahun 2011 tentang Badan Penyeleggara Jaminan Sosial (BPJS) 
This topic is very interesting both in theoretical and academic, for that writer is very interested to do research with the following reasons: First, that is still the lack of literature that examines the legal relationship with the National Social Security System which is a form of welfare provided by the State (Welfare state) to (BPJS) as the organizer of the National Health Insurance with the payment of the capitation system and the Indonesia Case Base Group (INA-CBGs), and with the issuance of Presidential Regulation No. 12 of 2013 on Health Insurance National Juncto President Number 111 Year 2013 on Health Insurance as guideline for the implementation of Health Insurance Program with participation of BPJS, and there is no regulation in West Kotawaringin regency that can fill the legal gap of Government policy.

According to Jimly Asshiddiqie that despite all expectations towards reform, democratization and liberalization, the concept of State welfare in the 1945 Constitution of the Republic of Indonesia is still a fundamental issue to ponder ${ }^{9}$. National Social Security System with Non-profit Social Security Administering Body (BPJS), in form as National Health Insurance provider throughout Indonesia. In West Kotawaringin district, BPJS of health cooperates with Puskesmas which only serve basic treatment on its participants during working hours 07.00 to 12.00 wib. BPJS of health also cooperates with Individual Practice Doctors who only serve basic treatment in the afternoon practice at 16.00 until 21.00 wib as First Level Health Facility (FKTP I). BPJS Health cooperates with Regional General Hospital (RSUD) as Advanced Health Facility (FKTP II). In practice many experience obstacles, it is seen by the many complaints from the community and from the provider. ${ }^{10}$

Related to this, according to WI Jenkins one of the important points of the policy definition is; that the policy is an act of government that aims to create public welfare and should be implemented by the organizational unit executor. ${ }^{11}$

Mursalim, Membedah Sistem Jaminan Sosial di Delapan Negara,

http://jamsos.blogspot.com/2013/02/membedah-sistem-jaminan-sosial-di.html

${ }^{9}$ Jawade Hafizh, Reformasi Kebijakan hukum Birokrasi Pengadaan Barang Dan Jasa Pemerintah Dalam Mencegah Terjadinya Tindak Pidana Korupsi di Indonesia, Disertasi, Semarang, 2014

${ }^{10}$ Paparan Kepala Dinas Kesehatan Kabupaten Kotawaringin Barat, 10 Maret 2015

${ }^{11}$ Ramesh Mishra, Welfare State in Crisis, Social Thought and social Change, Wheatsheaf Books Ltd,Harverster Press,London,1984, xi, Dalam Djauhari, , Politik Hukum Negara Kesejahteraan Indonesia, Semarang, Indonesia. 2008 
Increasing income also increases the rewards to workers and the existence of punishment to workers who do not have a good performance. This has an impact on the increasing motivation and creativity of workers in improving services to customers/ communities, so that the service is directed to the fulfillment of community needs as well as efforts to create social justice for the community.

This topic becomes very interesting because of different geographical conditions between one region with other areas so it takes the creativity of local governments in making policies that can provide legal certainty, and provide fair benefits for both Providers and for the community. Based on the description above, in this study the problem raised How to Reconstruct the National Social Security System of Health based on the value of welfare ${ }^{12}$

\section{B. Research Methods}

To answer the problem the researcher used constructive paradigm. The theory of constructivism states that the individual interprets and acts according to the conceptual categories of the mind. Reality does not describe the individual but must be filtered through people's perspective on that reality. This construtivism paradigm emphasizes the knowledge gained from experience or research which is then constructed to the extent of the experience or research it has. This construction process will run continuously because of the discovery of a new idea, which then can be used as the basis for formulating a system or regulation in the form of legislation that can be applied in everyday life.

The theory of constructivism is built on previous theories, namely personal construction or personal construct construction) by George Kelly. He states that people understand their experiences by grouping events according to their similarity and differentiating things through their differences.

The paradigm of constructivism is a paradigm that sees the truth of a social reality as a result of social construction, and the truth of a social reality is relative. This constructive paradigm is in the perspective of interpretivism (interpretation) which is divided into three types, namely

\footnotetext{
${ }^{12}$ Hanif Nurcholis,Teori dan Praktek Pemerintahan dan Otonomi Daerah, Grasindo, Jakarta, 2005
} 
symbolic interaction, phenomenological and hermeneutic. The paradigm of constructivism in social science is a critique of the positivist paradigm.

According to the constructivism paradigm of social reality observed by a person can not be generalized to all people, as is commonly practiced by positivists. The concept of the constructionist was introduced by an interpretative sociologist, Peter L. Berger with Thomas Luckman. In the concept of communication studies, social construction theory can be called to be between social fact theory and social definition.

To answer all issues in a comprehensive manner the research approach that researchers use is socio legal research, this research approach is chosen to see how far the effectiveness of law in the prosperity of the community, especially in the protection of health insurance, here the law is not only seen in terms of its effectiveness but also related With non-legal factors such as institutions related to the welfare of the community.

This approach is also done to understand the law within the context of its society. By Briand $Z$ Tamanaha it is said that between law and society has a frame called "the law society framework" which has certain relationship characteristics. The relationship is shown by two basic components. The first component consists of two main themes namely the idea that the law is the mirror of society and the idea is the function of law to maintain the "social order". The second component consists of three elements, namely: custom/ consent; Morality/ reason; And positive law custom/ consent and morality/ ideas can be understood in Donald Blak's thinking as a culture.

\section{Research Results and Discussion.}

Objectives of the research is to understand and to analyze the National Social Security System Construction of Health Sector in the current positive law, to understand and analyze the weaknesses of the National Social Security System for Health Sector at this time and To analyze and reconstruct the National Social Security System for Health Sector Welfare-based Research is expected to have both theoretical and practical uses. BPJS Health as the contents of article 60 of Law RI Number 24 of 2011 on BPJS began operating a concerted health insurance 
program in Indonesia starting on January $1,2014^{13}$. Since the operation of this BPJS Health then all existing social security providers or social insurance before Apply again. As a technical guideline for the implementation of BPJS Health, issued Presidential Regulation No. 12 of 2013 on National Health Insurance Juncto Presidential Regulation No. 111 of 2013 on National Health Insurance, then in the implementation of this National Health Insurance (BPK) program BPJS Health in cooperation with Public Health Facility as well Private, but in the implementation that until now the government has not been able to balance between the desire to provide assurance of protection to all Indonesian people with the availability of health facilities in justice for all the people of Indonesia.

Social Security System Practices in Several Countries (Wisdom International).

Basically the practice of the Social Security System in the Health Sector in some countries is the State's obligation in providing basic needs for its citizens (Welfare State). The following social security provisions in some countries are as follows:

\section{Malaysia}

The social security system in Malaysia includes:

Employee Provident Fund (EPF) mandatory savings program through EPF Ordinance. All private employees and civil servants who are not eligible for retirement must follow the EPF program. The contribution rate for the EPF program in wage percentages increases from year to year. The amount of the contribution is increased gradually to adjust to the wage rate and the level of ability of the savings population. In the EPF program in Malaysia, once someone follows the program, he/she must continue to be a participant until he / she enters retirement age which is still 55 years old.

\section{South Korea ${ }^{14}$}

\footnotetext{
${ }^{13}$ Undang-Undang Nomor 24 Tahun 2011 tentang Badan Penyeleggara Jaminan Sosial (BPJS)

${ }^{14}$ Luqman Hakim,2011,Implementasi Kebijakan Pelayanan Kesehatan di Korea Selatan, Jurnal Internasional, Korean Studies Indonesia
} 
South Korea started its social security by developing compulsory health insurance in 1976 after 13 years of failing to develop voluntary health insurance. As for the informal sector, the Law regulates the income levels for each group and the amount of contributions is set separately for each income group. While the contribution to the pension plan is now $9 \%$ of wages paid jointly between employers and workers respectively by $4.5 \%$. In the initial stage the contribution was only $3 \%$, then gradually improved to now reach $9 \%$. In addition to workers, the NPC also serves the volunteer population, individually or informal sector workers, registering for current contributions of $7 \%$, but will also be increased so that 2005 will contribute $9 \%$. In South Korea, the public awareness to be a participant of self-supporting social insurance (compulsory health insurance) is very high, now has reached $100 \%$ of the population into the compulsory health insurance participant and entirely actively pay the dues. Percentage of the State provides compulsory contributions to the very poor, only $3 \%$ of the total number of currently $48,598,175$ people, the key to successful Social Security in South Korea is the reform of health services through the provision of appropriate health facilities by the Government Equitable and fair and a very high public awareness to pay membership dues.

\section{United States}

Social security in America was first enacted on 14 August 1935 under the name OASDI program (Old-Age, Survivors, and Disability Insurance). Initially, the American Social Security Act does not cover social health insurance (Medicare). Contributions to social security programs are collected together with general tax payments and are therefore called social security taxes. It's just that social security funds do not go into the state treasury but into three types of funds (trust funds) namely Old Age and Old Age Guarantee Fund (Old-age and Survivors Insurance, OASI), Disability Insurance Fund (SSDI), and Fund Medicare. The amount of labor contribution is $7.65 \%$ and employers also contribute $7.65 \%$ for the OASI program and $0.9 \%$ each for the SSDI program, and $1.45 \%$ for the Medicare program respectively. The total contribution of workers to $15.3 \%$ of wages with a maximum wage of US $\$ 62,500$ a year is annually raised in accordance with the index prepared by the organizing body (SSA) under the Ministry of Social Services. 
Based on the study of international wisdom, the authors conclude the principle of benefits and facilities of health care providers and health insurance payment systems in each country, the results of this study are intended for the authors to get an ideal picture of the benefits and facilities of health care providers of these three (3) Can be adopted and can be applied in Indonesia in the National Social Security System of Health Sector In the era of Regional Autonomy Based on Welfare Value.

However, given the potential differences in each region in Indonesia and the consideration of the extent of the territory, and the distribution of people in remote and very remote areas that are uneven, if the fulfillment of health facilities should be in accordance with the Minister of Health Regulation No. 24 of 2014 on Class D Pratama Hospital Other types of hospitals, it will take a long time, because the requirements are quite complicated such as the ratio of population to the number of human resources in health facilities, the number and facilities to be completed, is still difficult to implement in the Region in a short time, while the current community demands The greater the ease of accessing quality services, fast and affordable and fair should be realized by the Government and Local Government.

\section{Values Being the Basic of Reconstruction of Health SJSN Implementation}

\section{The Value of Justice and People's Welfare}

The precepts of social justice for all Indonesians mean that the people of Indonesia are aware of the same rights and obligations to create social justice in Indonesian society. ${ }^{15}$ Social justice has an element of equality, equality and freedom of a communal nature. Justice for all the people of Indonesia in obtaining social security in the field of health is a State obligation that must be realized as a manifestation of the sincerity of the Government provide basic services which are the fundamental rights of the community. In the 1945 Constitution of the State of the Republic of Indonesia Article $28 \mathrm{H}$ paragraph (2) Everyone shall have the right to special convenience and

${ }^{15}$ Djauhari, Politik Hukum Negara Kesejahteraan Indonesia). 2008, 
treatment to obtain equal opportunities and benefits to achieve equality and justice, paragraph (3) every person shall have the right to social security His complete development as a dignified human being. ${ }^{16}$

On this basis the authors propose the reconstruction of the implementation of the National Social Security System in the field of Health with reference to the value of justice and welfare of the people through strengthening the legal system. Reconstruction of the SJSN for Health Sector based on Pancasila (Wisdom Local).

By looking at the real conditions in the field, it can clearly be seen that by adopting the legal system of other countries, indirectly Indonesia has adopted the ideology of the country. The legal system of each State must be guided by the Constitution which is derived from the ideological values of each State, so that this adoption will limit Indonesia to the legal culture of Indonesian society ${ }^{17}$. Therefore, the implementation of SJSN in the field of health can not be implemented in accordance with the objectives of the State listed in paragraph 4 of the 1945 Constitution which is to give the welfare to all the Indonesian People in justice based on Pancasila with 45 points as stipulated by TAP MPR Number 1 Year 2003 as indicators of implementation and The success of the Government program.

The second principle of Pancasila contains values such as (1) Confessing and treating human beings according to their dignity and dignity as creatures of God Almighty; (2) Acknowledging the equality, equality of rights, and fundamental obligations of every human being, without distinction of race, heredity, religion, belief, sex, social standing, skin color and so on; (3) Develop mutual loving attitude among human beings; (4) Develop an attitude of mutual tolerance and tolerance; (5) Developing a non-arbitrary attitude toward others; (6) upholding human values; (7) Fond of doing humanitarian activities. ${ }^{18}$

Based on the five principles of Social Justice for the People of Indonesia, the implementation should refer to the 11 points of Pancasila from the precepts as an indicator of success ${ }^{19}$ : (1) Developing noble

\footnotetext{
${ }^{16}$ Agung Kurniawan, Trasnformasi Pelayanan Publik, Pembaharuan, Yogyakarta, , 2003

${ }^{17}$ Esmi Warassih, Pranata Hukum Sebuah Telaah Sosiologis, Suryandaru Utama, Semarang, 2005

${ }^{18}$ Agung Kurniawan, Trasnformasi Pelayanan Publik, Pembaharuan, Yogyakarta, , 2003

${ }^{19}$ Ronny Hanitijo Soemitro, Perspektif Sosial Dalam Pemhaman Masalah-Masalah Hukum,

CN.. Agung, Semarang, , 1989
} 
deeds, reflecting the attitude and atmosphere of family and mutual cooperation; (2) Developing a fair attitude toward others; (3) Maintaining a balance between rights and obligations; (4) Respecting the rights of others; (5) Likes to give help to others to stand on their own; (6) Not exercising property rights for extortionary efforts against others; (7) Not using property rights for wastes and fancy lifestyles; (8) Not using property rights for things that are contrary to or public interest; (9) Likes to work hard; (10) Likes to appreciate the work of others who are beneficial to progress and common prosperity; (11) Likes to carry out activities in realizing equitable and equitable progress.

The linkage of the points of Pancasila First Precepts, the Second Precepts and the Fifth Precepts is aimed at restoring the behavior and manners of Indonesian citizens to fit the philosophy and culture of the Indonesian nation, which, according to the writer's observation that there has been liberalization and the emergence of individualistic individuals .

\section{Reconstruction of Legal Substance in Presidential Regulation No. 12 of 2013 on National HealthInsurance.}

Referring to the implementation of health BPJS which still have weaknesses that cause this program can not be implemented properly, then found component of Substance of law which need to be reconstructed because not yet able to give benefit which is Presidential Regulation Number 12 Year 2013 about National Health Insurance. According to Bentham is the principle that tells everyone to do what brings about the greatest happiness or enjoyment that everyone desires for as many people as possible or for society as a whole. Therefore, according to the utilitarian view, the ultimate goal of man, must also be a measure of morality. From here, the phrase 'the end justifies the means'.

According to William J. Chambliss and Robert B. Seidmen that to measure an innovation requires engineering over the operation of the law, in addition to law serving as a tool for social control, the law can also be used as a tool for social engineering $A$ tool of social engineering), as described by Roscou Pound.

The operational conception of the workings of the law in society is based on two different concepts, namely the concept of predictions of consequences proposed by Lunberg and Lansing in 1973 and Hans 
Kelsen's concept of the dual aspects of a particular regulation. Based on the concept of Lunbreg and Lansing and Hans Kelsen's concept Robert B. Seidmen and william J. Chambliss drafted the theory of legal work in society, the outline of the work of law in society will be determined by several major factors; 1). Factors that are normative juridical (law-making), 2). Factors of enforcement (the parties and the role of government), 3). Sociological juridical factors (concerning economic considerations and the legal culture of the offender). ${ }^{20}$

According to Antony Allot, that effective law should generally be carried out in accordance with its objectives, in the event of a failure, there should be possibilities and means of easy repairs. When required to apply the law under different or new circumstances, the law must be sufficiently customizable.

Effective laws should generally do what they are designed to do; If some failure occurs, there should be the possibility and means of easy rectification. If the necessity comes to aplly the law in different or new circumstances, the law should be sufficiently adaptable.

According to Philippe Nonet and Philip Selnick in perceptive responsive laws that good law should offer something more than procedural justice. The good law must be competent and fair, the law should be able to concern the public will and be committed to the achievement of substantive justice. The Responsive Theory by Phillippe Nonet and Philip Selnick points out the systematic interconnections of law in society: 1). Law as a servant of repressive power; 2) law as a separate institution capable of taming repression and protecting its integrity; And 3) law as facilitator of various responses to social needs and aspirations.

The presence of progressive law that departs from the basic assumption that the law is for human beings, law enforcers should not only understand the positive law that is in effect, but how law enforcers can lift the legal values that lead to real justice, not just health . Not only understand the positive law that has been applied, but how law enforcers are able to lift the legal values that lead to real justice, not just justice based on a series of words or sentences of legislation only, but rather on justice That is real.

\footnotetext{
${ }^{20}$ Nomensen Sinamo,Hukum Administrasi Negara, Jala Permata Aksara, Jakarta, 2012
} 
In this context, every human being has individual responsibility and social responsibility to give justice to anyone. Prioritizing behavior (human) rather than legislation as the starting point of law enforcement paradigm, will provide legal understanding as a humanitarian process.

According to Satjipto Raharjo: the law should follow the development of the times, be able to answer the problems developed in society, and able to serve the community by relying on the aspect of morality and law enforcement own resources This idea emerges in response to the positivistic paradigm that makes the collapse of the law. ${ }^{21}$

\section{Table 9}

\section{Proposal of Reconstruction of Substance of Social Security Law of Welfare Based Welfare Field}

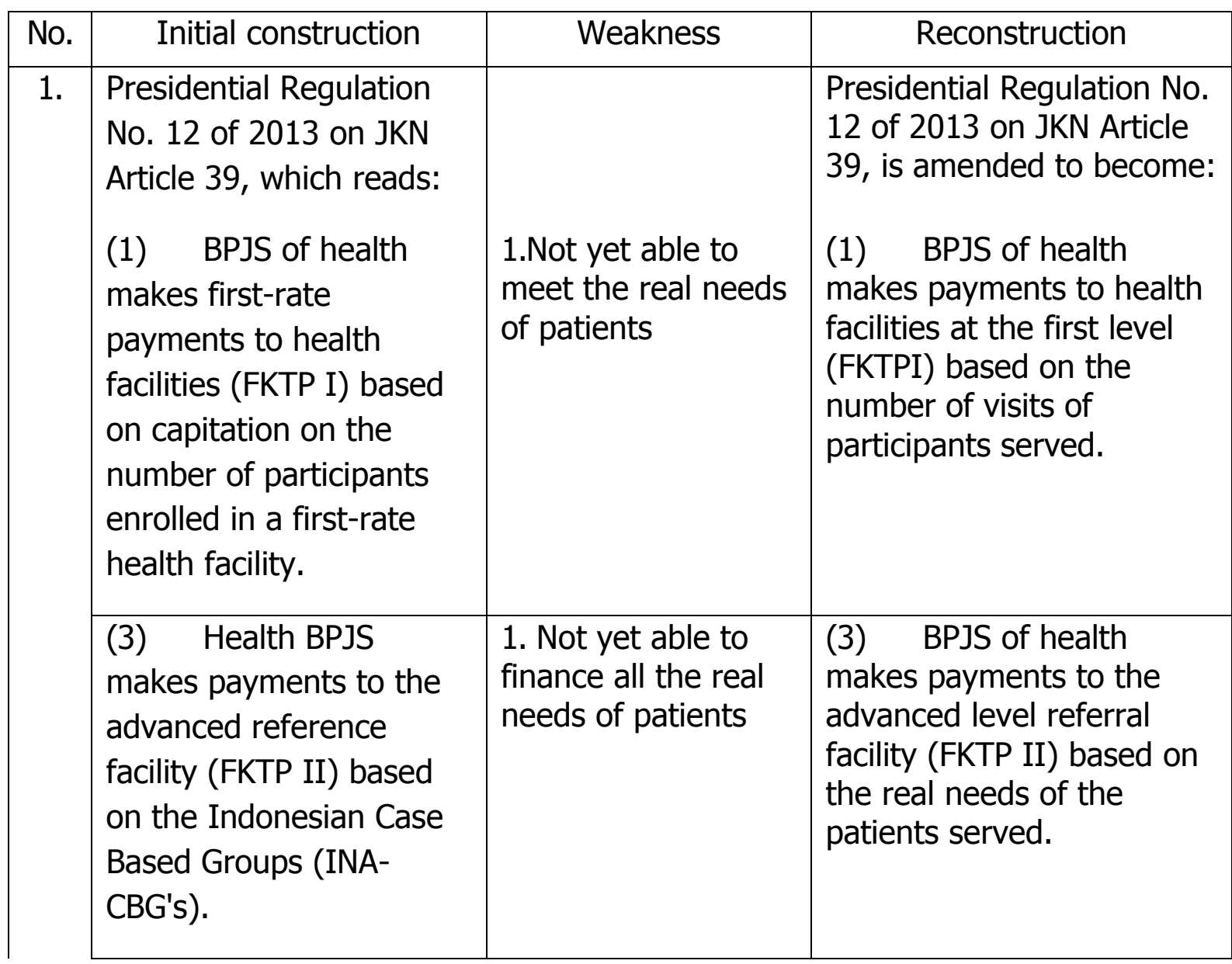

\footnotetext{
${ }^{21}$ Suteki, Rekosntruksi Politik Hukum tentang Hak Menguasai Negara Atas Sumber DayaBerbasis Nilai Keadilan Sosial, Disertasi, Semarang, 2008.
} 


\begin{tabular}{|c|c|c|c|}
\hline No. & Initial construction & Weakness & Reconstruction \\
\hline & $\begin{array}{l}\text { (4) Capacity size and } \\
\text { Indonesian Case based } \\
\text { Groups (INA-CBG's) are } \\
\text { reviewed at least every } 2 \\
\text { (two) years by the } \\
\text { Minister after } \\
\text { coordinating with the } \\
\text { Minister who conducts } \\
\text { government affairs in } \\
\text { finance }\end{array}$ & $\begin{array}{l}\text { 1. The potential of } \\
\text { each region is } \\
\text { different. }\end{array}$ & $\begin{array}{l}\text { (4) The amount of } \\
\text { health service tariff is } \\
\text { adjusted to the real needs } \\
\text { of patients in each region. }\end{array}$ \\
\hline 2. & $\begin{array}{l}\text { Presidential Regulation } \\
\text { No. } 111 \text { of } 2013 \text { on JKN, } \\
\text { Article } 22 \text { reads: } \\
\text { The guaranteed health } \\
\text { services consist of non- } \\
\text { specialist health services } \\
\text { which include: service } \\
\text { administration, } \\
\text { promotive and } \\
\text { preventive services, } \\
\text { examination, treatment, } \\
\text { medical consultation, } \\
\text { non-specialist medical } \\
\text { treatment, operative and } \\
\text { non operative, drug and } \\
\text { consumables services, } \\
\text { blood transfusion as } \\
\text { required Medical, basic } \\
\text { laboratory diagnostic } \\
\text { investigation, first-rate } \\
\text { hospitalization as per }\end{array}$ & $\begin{array}{l}\text { The task of FKTP I } \\
\text { goes beyond the } \\
\text { ability of individual } \\
\text { practitioner } \\
\text { physicians, as well } \\
\text { as Puskesmas, } \\
\text { blood transfusion } \\
\text { has not been } \\
\text { possible in FKTP I. }\end{array}$ & $\begin{array}{l}\text { Presidential Regulation No. } \\
111 \text { of } 2013 \text { on JKN, Article } \\
22 \text { reads: } \\
\text { Guaranteed health services } \\
\text { consist of non-specialist } \\
\text { health services covering: } \\
\text { service administration, } \\
\text { promotive and } \\
\text { preventive services, } \\
\text { examination, treatment, } \\
\text { medical consultation, } \\
\text { non-specialized } \\
\text { operative and non- } \\
\text { operative medical } \\
\text { procedures, drug and } \\
\text { consumables services, } \\
\text { laboratory diagnostic } \\
\text { support Basic, first-line } \\
\text { hospitalization according } \\
\text { to medical indication. }\end{array}$ \\
\hline
\end{tabular}

${ }^{22}$ Keluhan eks peserta Askes Bahrudin dan Isnaniah eks peserta Jamkesmas, saat wawancara di poli rawat jalan RSUD Sultan Imanuddin dan Puskesmas, pada 15 Maret 2014. 


\begin{tabular}{|l|l|l|l|}
\hline No. & Initial construction & Weakness & Reconstruction \\
\hline & medical indication. & & \\
& & & \\
\hline
\end{tabular}

\section{Reconstruction of the Legal Structure of the National Social Security System for Justice and Welfare Value-Based Health.}

Article 35 Paragraph (1) of Presidential Regulation No. 12 of 2013 on Responsibility for Availability of Health Facilities and Provision of Health Services, that the Government and Local Government are responsible for the availability of health facilities and the provision of health services for the implementation of the health insurance program. Thus the authority of the government has traits such as: 1). Exspess implied; 2) .the purpose; 3). Bound at a certain time; 4) subject to written and unwritten legal restrictions; And 5). The content of authority can be general (abstract) and concrete. As the theory of respresive law that drab Phillippe Nonet and Philip Selnick namely; Some form of repression can manifest itself, one side is the inability of the government to meet the general demands and on the other is the government that transgresses the limits. Proposal Strengthening the Legal Structure of SJSN Health Sector With the Establishment of Centralized Production of Health Devices Based on the Value of Justice and Welfare.

As is well known, that the biggest financing in the health sector is on the financing of health equipment and its maintenance. This is because the Government until now provide signs for the procurement of goods / services of health equipment, more directed to the imported health equipment specifications, so in addition to the expensive price also does not provide an opportunity for health equipment experts (bachelors atem) Indonesia to play a role in producing these medical devices.

Proposed Strengthening of SJSN Law Culture Health Sector Diera Regional Autonomy based on Welfare Value.

The weaknesses of substance and legal structure that have been described previously, have an impact on the weakness of the legal culture of society. Culture The law that grows in society is a social force that determines whether a rule (positive law) works effectively in society. As good as any positive law is made, but if it is not in line with the culture of 
community law, then the positive law is just a barrage of words. Law should be seen as a symptom that can be observed in society, among others through the behavior of citizens. This means that the point of attention should be addressed to the relationship between law and other non-legal factors, especially the value factor and attitude and the public view, hereinafter referred to as the legal culture.

\section{Conclusion}

Based on the above, it can be seen that the Legal System of the Health Insurance Program with the participation of BPJS is still very weak both in terms of the legal substance component, in providing equitable welfare in obtaining health services through the Health Insurance Program with the participation of BPJS, as follows:

1. Strengthening the Components of the Substance of the Law by changing Article 39 Paragraphs (1), (3) and (4) of Presidential Regulation No. 12 of 2013 on the procedure of payment of BPJS to First Level Medical Facility (FKTP I) or BPJS payment at Health Facility Referral Level (FKTP II) towards more efficient payments in accordance with the real needs and financing of the patients served.

2. Strengthening Legal Structure Components by Strengthening the FKTP I in the form of regulations either Government Regulation or Presidential Regulation as a National Policy that break down into the Regulation of the Minister of Health of RI and Regional Regulation as a Regional Policy whose substance regulates budgeting obligations, fulfillment of human resources, Decent health, coaching and evaluation of health services.

3. Strengthening the Components of Legal Culture by developing the culture of community law through continuous education to the community so that the economically categorized people become aware of their obligations to pay BPJS dues regularly and provide education to the officers at the health facility on the development of personality in accordance with the grain- The grains of Pancasila Sila 1 Belief in the One and the Second Practice of Just and Civilized Humanity and the 5th Precept of Social Justice for All Indonesians.

4. The government is not responsible for providing funds for Beneficiaries (PBI), but the government is responsible for direct financing and equitable provision of health facilities equitably, people are only subject to free tariffs on state-owned health facilities when they fall ill. 


\section{BIBLIOGRAPHY}

\section{BOOKS :}

Ali Taher Parasong, Mencegah Runtuhnya Hukum, Grafindo, Jakarta, 2014 Agung Kurniawan, Trasnformasi Pelayanan Publik, Pembaharuan, Yogyakarta, , 2003

Antony Allot, The limit Of Law, London-Butterworths, 1980

Depkes RI, Pedoman Pelaksanaan Jaminan Pemeliharaan Kesehatan Masyarakat Miskin, Jakarta ,2006

Djauhari, Politik Hukum Negara Kesejahteraan Indonesia). 2008,

Esmi Warassih, Pranata Hukum Sebuah Telaah Sosiologis, Suryandaru Utama, Semarang, 2005

Hanif Nurcholis, Teori dan Praktek Pemerintahan dan Otonomi Daerah, Grasindo, Jakarta, 2005

Hartono,Penyidikan dan Penegakkan Hukum Pidana Melalui Pendekatan Hukum Progresif, Sinar Grafika, Jakarta, 2010

Jawade Hafizh, Reformasi Kebijakan hukum Birokrasi Pengadaan Barang Dan Jasa Pemerintah Dalam Mencegah Terjadinya Tindak Pidana Korupsi di Indonesia, Disertasi, Semarang, 2014

Margaretha Yuliani, Menyongsong BPJS Kesehatan 2014 ,Jaminan Kesehatan :Hak Rakyat-Kewajiban Negara, Depkes RI,Jakarta, 2013

Nomensen Sinamo,Hukum Administrasi Negara, Jala Permata Aksara, Jakarta, 2012

Ramesh Mishra, Welfare State in Crisis, Social Thought and social Change, Wheatsheaf Books Ltd,Harverster Press,London,1984, xi, Dalam Djauhari, , Politik Hukum Negara Kesejahteraan Indonesia, Semarang, Indonesia. 2008

Ronny Hanitijo Soemitro, Perspektif Sosial Dalam Pemhaman MasalahMasalah Hukum, CN.. Agung, Semarang, , 1989

Suteki, Rekosntruksi Politik Hukum tentang Hak Menguasai Negara Atas Sumber Daya Berbasis Nilai Keadilan Sosial, Disertasi, Semarang, 2008. 
JOURNAL :

Luqman Hakim,2011,Implementasi Kebijakan Pelayanan Kesehatan di Korea Selatan, Jurnal Internasional, Korean Studies Indonesia

\section{ETC:}

Keluhan eks peserta Askes Bahrudin dan Isnaniah eks peserta Jamkesmas, saat wawancara di poli rawat jalan RSUD Sultan Imanuddin dan Puskesmas, pada 15 Maret 2014.

Paparan Kepala Dinas Kesehatan Kabupaten Kotawaringin Barat, 10 Maret 2015

Pidato Pengukuhan Guru Besar , FH UI ,Lebih lanjut dikatakan bahwa perkembangan kearah liberalisasi, baik dibidang politik maupun ekonomi dewasa ini dan akan cenderung meningkat dimasa depan, secara mendasar merupakan gugatan eksistensi terhadap prinsip Negara kesejahteraan.Konstitusi Negara kesejahteraan danRealitas Masa Depan, , 1998

Wawancara dengan Pimpinan Puskesmas Mendawai, dr Alita Gati, pada tanggal 20 Maret 2014.

Wawancara dengan Rekam Medik RSUD Sultan Imanudin, Dwi Supriyanti, pada tanggal 21 Maret 2014.

Wawancara dengan Sri Astuti, tenaga Administrasi Puskesmas Arsel, pada tanggal 10 Mei 2014.

\section{INTERNET :}

Departemen Kesehatan, diunduh pada tanggal 12 maret 2014 pada situs yang beralamat,http://www.depkes.go.id/downloads/SKN\%20final.pdf

Undang-Undang Nomor 24 Tahun 2011 tentang Badan Penyeleggara Jaminan Sosial (BPJS)

Mursalim, Membedah Sistem Jaminan Sosial di Delapan Negara , http://jamsos.blogspot.com/2013/02/membedah-sistem-jaminansosial-di.html 
Diunduh pada tanggal 12 maret 2014, dari situs yang beralamat di http://repository.usu.ac.id/bitstream/123456789/38405/3/Chapter\%20 II.pdf

\section{CONSTITUTION :}

Undang-undang Nomor 36 Tahun 2009 tentang Kesehatan 